Itang

\title{
PENYEBAB KEMISKINAN DAN CARA MENANGGULANGINYA
}

\begin{abstract}
Abstrak
Kemiskinan merupakan masalah klasik yang mesti dicari penyebab dan penanggulangannya. Diantara penyebabnya ada beberapa faktor yaitu faktor individual, faktor keluarga, faktor sub-budaya (subcultural), faktor agensi, dan faktor struktural dan berdampak pada pengangguran, kriminalitas, kesehatan, putus sekolah dan buruknya generasi penerus. Sedangkan cara menanggulanginya yang dilakukan pemerintah dengan berbagai cara, yaitu dengan program PNPM Mandiri dengan pemenuhan atas sandang dan pangan, penyediaan perumahan layak huni, jaminan kesehatan dan pendidikan.
\end{abstract}

Kata Kunci: Penanggulangan, kemiskinan.

\section{Pendahuluan}

Secara etimologi kemiskinan berasal dari kata miskin, yaitu tidak berharta benda atau serba kurang. ${ }^{1}$ Sedangkan kemiskinan secara terminologi menurut Sorjono Soekanto ${ }^{2}$ mengartikan tentang kemiskinan sebagai suatu keadaan dimana seseorang tidak sanggup memelihara dirinya sesuai dengan taraf kehidupan kelompok dan juga tidak mampu memanfaatkan tenaga, mental maupun fisiknya dalam kelompok tersebut. Kenyataan menunjukkan bahwa kemiskinan masih terdapat pada penduduk negara-negara berkembang termasuk di Indonesia. Kemiskinan sering dihubungkan dengan keterbelakangan dan ketertinggalan. Di samping itu kemiskinan juga merupakan salah satu masalah sosial yang amat serius. Untuk mencari solusi yang relevan dalam pemecahan masalah kemiskinan, perlu dipahami sebab musabab dan menelusuri akar permasalahan kemiskinan itu.

Batasan kemiskinan umumnya diukur dengan membandingkan tingkat pendapatan yang diperlukan untuk memenuhi kebutuhan hidup minimum atau layak. Selanjutnya dikatakan bahwa tingkat pendapatan minimum itulah yang dipergunakan sebagai pembatas antara keadaan miskin dan tidak miskin yang disebut poverty line (garis kemiskinan). Bagi masyarakat Indonesia, beras dipandang sebagai komoditi kebutuhan pokok yang besar pengaruhnya. Komoditi ini elastis, artinya perubahan harga beras mempengaruhi komoditi lainnya. Oleh karena itu beras dapat digunakan sebagai dasar penentuan garis kemiskinan. 
Indonesia memiliki persoalan kemiskinan dan pengangguran. Kemiskinan di Indonesia dapat dilihat dari tiga pendekatan yaitu kemiskinan alamiah, kemiskinan struktural, dan kesenjangan antar wilayah. Persoalan pengangguran lebih dipicu oleh rendahnya kesempatan dan peluang kerja. Upaya untuk menanggulanginya harus menggunakan pendekatan multi disiplin yang berdimensi pemberdayaan. Pemberdayaan yang tepat harus memadukan aspek-aspek penyadaran, peningkatan kapasitas, dan pendayagunaan. ${ }^{3}$

Kemiskinan lahir sebagai dampak dari proses pembangunan yang tidak mencapai target kepada sebuah perbaikan sosial. Setiap pembahasan tentang pembangunan, maka pembahasan kemiskinan mendapatkan tempat yang cukup penting. Masalah kemiskinan di Indonesia telah menjadi topik pembicaraan dan fokus kebijakan sejak pemerintahan kolonial Belanda dengan meluncurkan suatu program anti kemiskinan lewat kebijakan yang dikenal dengan "politik etis".

Kemiskinan bukanlah merupakan sesuatu yang tidak berbentuk (amorfhous), tetapi merupakan fenomena yang bersifat kompleks dan multidimensional. ${ }^{5}$ Beberapa kategori miskin seperti yang dikemukakan oleh Sri Mulyani ${ }^{6}$ adalah tidak terpenuhinya kalori sebanyak 2300 grm per hari yang di konsumsi oleh masyarakat. Sedangkan menurut para ulama ${ }^{7}$ yaitu ; (1). Madzhab Hanafi kategori miskin adalah orang yang tidak memiliki suatu apapun, sehingga terdorong untuk meminta-minta bahan makanan dalam memenuhi kebutuhan hidupnya sehari-hari. (2). Madzhab Maliki kategori miskin adalah orang yang tidak memiliki sesuatu apapun. (3). Madzhab Hambali kategori miskin adalah orang yang dapat memperoleh separoh kecukupannya atau lebih. (4). Madzhab Syafi' 'i ${ }^{8}$ kategori miskin adalah orang yang memiliki separoh dari kebutuhan dan yang separoh lagi dipenuhi dengan zakat.

Menurut Gunawan Sumodiningrat ${ }^{9}$ kemiskinan dapat dibedakan dalam tiga pengertian yaitu : Pertama kemiskinan absolut yaitu apabila pendapatan seseorang tidak mencukupi dari kebutuhan hidup minimum, antara lain kebutuhan pangan, sandang, kesehatan, perumahan dan pendidikan yang diperlukan untuk hidup dan bekerja. Rendahnya tingkat pendapatan ini terutama disebabkan oleh keterbatasan sarana dan prasarana fisik serta kelangkaan modal atau miskin karena sebab alami (natural). Kedua Kemiskinan kultural yaitu mengacu pada sikap seseorang atau masyarakat yang (disebabkan oleh faktor budaya) tidak mau berusaha untuk memperbaiki tingkat kehidupan meskipun ada usaha dari pihak luar untuk membantunya. Ketiga kemiskinan relatif yaitu erat kaitannya dengan masalah pembangunan yang sifatnya struktural. Yakni kebijaksaan pembangunan yang belum seimbang menyebabkan ketimpangan pendapatan.

Beberapa pendapat lain tentang kategori kemiskinan diantaranya yaitu ${ }^{10}:$ (1). Murjanto Danusaputro, kemiskinan adalah pendapatan sebesar $320 \mathrm{~kg}$ ekuivalen besar untuk penduduk di kota atau $240 \mathrm{~kg}$ untuk penduduk di pedesaan setahunnya. (2). Moh. Bambang Agustin, miskin itu masih lebih baik, karena masih ada yang lebih sengsara lagi yaitu fakir miskin. Fakir miskin sudah tidak punya apa-apa sama 
sekali, martabat tidak punya, baju tidak punya. (3). Firdaus Wadjdi, miskin yaitu apa bila orang tua tidak dapat membiayai anaknya sekolah. Ini sudah termasuk kategori miskin.

Menurut Dalil Hasan ${ }^{11}$ ciri-ciri penduduk miskin yaitu: (1). Kelompok miskin ditingkat pedesaan; umumnya terdiri dari petani kecil /petani marginal/ pekerja pertanian /buruh tani, nelayan kecil, pengrajin kecil, pengangkut kecil (grobak, becak, dokar/delman, ojek) dan sebagainya. (2). kelompok miskin ditingkat perkotaan; umumnya terdiri dari pekerja harian di pabrik, pekerja harian di bangunan, pedagang kaki lima, pedagang asongan, pengerajin kecil, pengusaha kecil (kios, warung, tenda, greobak, bengkel kecil, pengemudi harian (gerobak, ojek, dokar, becak, dan sebagainya). tukang jahit, tukang reparasi, (sepeda/jam/sepatu). Pembantu rumah tangga kecil, pemulung dan sebagainya. (3). Umumnya penduduk miskin tidak mempunyai pendapatan tetap, tetapi harus puas dengan pendapatan tidak tetap/berubah/bervariasi namun masih tetap dibawah batas pendapatan minimal. (4). Sebagian besar penduduk miskin tidak bekerja secara penuh (fultimer). Tidak memperoleh jaminan kesehatan/jaminan hari tua/perlindungan kerja, tidak memperoleh tingkat upah kerja minimum yang ditetapkan oleh pemda untuk berbagai jenis pekerjaan dan berbagai kota/daerah, tidak memperoleh upah lembur, tidak memperoleh hak cuti, memperoleh sedikit pendidikan /latihan latihan dan memiliki etos kerja yang sangat rendah.(5). Penduduk miskin pada umumnya tidak memiliki peralatan produksi /peralatan kerja yang memadai, misalnya pemilikan tanah yang sangat sempit (rata-rata 0,25 Ha per kepala keluarga tani di Pulau Jawa), tanah marginal (tidak /kurang subur, lokasinya yang tidak menguntungkan karena letaknya di daerah aliran sungai (DAS), di atas bukit/pegunungan, di pinggir hutan, di rawarawa). Di samping itu, kepala rumah tangga mempunyai tanggungan keluarga yang relative tinggi (height dependency ration). (6). Tingkat pendidikan miskin pada umumnya sangat rendah (SD), bahkan sebagian peduduk miskin sebagian samasekali tidak memperoleh pendidikan formal/tidak dapat menulis dan membaca.

\section{Faktor Penyebab Kemiskinan}

Penyebab kemiskinan menurut Kuncoro yaitu: ${ }^{12}$

1. Secara makro, kemiskinan muncul karena adanya ketidaksamaan pola kepemilikan sumber daya yang menimbulkan distribusi pendapatan timpang, penduduk miskin hanya memiliki sumber daya dalam jumlah yang terbatas dan kualitasnya rendah.

2. Kemiskinan muncul akibat perbedaan kualitas sumber daya manusia karena kualitas sumber daya manusia yang rendah berarti produktivitas juga rendah, upahnya pun rendah.

3. Kemiskinan muncul sebab perbedaan akses dan modal. Akibat keterbatasan dan ketertiadaan akses manusia mempunyai keterbatasan (bahkan tidak ada) pilihan untuk mengembangkan hidupnya, kecuali menjalankan apa terpaksa saat ini yang dapat dilakukan (bukan apa yang seharusnya dilakukan). Dengan demikian 
manusia mempunyai keterbatasan dalam melakukan pilihan, akibatnya potensi manusia untuk mengembangkan hidupnya menjadi terhambat. Kemiskinan juga muncul karena adanya perbedaan kualitas sumber daya manusia, karena jika kualitas manusianya rendah pasti akan mempengaruhi yang lain, seperti pendapatan. Tapi itu hanyalah masalah klasik. Sekarang penyebab kemiskinan adalah karena tidak mempunyai uang yang banyak. Orang yang mempunyai uang banyak, mereka dapat meningkatkan kualitas hidupnya karena mereka dapat bersekolah ke jenjang yang lebih tinggi. Berbeda dengan orang miskin yang tidak punya uang banyak, mereka tidak dapat bersekolah yang lebih tinggi karena mereka tidak punya uang lagi untuk membiayai uang sekolah seperti masuk perguruan tinggi atau SMA.

Kemiskinan juga banyak dihubungkan dengan: ${ }^{13}$

1. Penyebab individual, atau patologis, yang melihat kemiskinan sebagai akibat dari perilaku, pilihan, atau kemampuan dari si miskin.

2. Penyebab keluarga, yang menghubungkan kemiskinan dengan pendidikan keluarga.

3. Penyebab sub-budaya (subcultural), yang menghubungkan kemiskinan dengan kehidupan sehari-hari, dipelajari atau dijalankan dalam lingkungan sekitar.

4. Penyebab agensi, yang melihat kemiskinan sebagai akibat dari aksi orang lain, termasuk perang, pemerintah, dan ekonomi.

5. Penyebab struktural, yang memberikan alasan bahwa kemiskinan merupakan hasil dari struktur sosial.

Meskipun diterima luas bahwa kemiskinan dan pengangguran adalah sebagai akibat dari kemalasan, namun di Amerika Serikat (negara terkaya per kapita di dunia) misalnya memiliki jutaan masyarakat yang diistilahkan sebagai pekerja miskin; yaitu, orang yang tidak sejahtera atau rencana bantuan publik, namun masih gagal melewati atas garis kemiskinan.

Penyebab kemiskinan terbagi menjadi dua faktor, yaitu faktor eksternal dan internal: ${ }^{14}$

\section{a. Faktor Internal}

1. Sikap. Sikap berarti suatu keadaan jiwa dan keadaan pikir yang dipersiapkan untuk memberikan tanggapan terhadap suatu objek yang diorganisasi melalui pengalaman dan mempengaruhi secara langsung pada perilaku. Keadaan jiwa tersebut sangat dipengaruhi oleh tradisi, kebiasaan, kebudayaan dan lingkungan sosialnya.b

2. Pengalaman dan pengamatan. Pengalaman dapat mempengaruhi pengamatan sosial dalam tingkah laku, pengalaman dapat diperoleh dari semua tindakannya dimasa lalu dan dapat dipelajari, melalui belajar orang akan dapat memperoleh pengalaman. Hasil dari pengalaman sosial akan dapat membentuk pandangan terhadap suatu objek. 
3. Kepribadian. Kepribadian adalah konfigurasi karakteristik individu dan cara berperilaku yang menentukan perbedaan perilaku dari setiap individu.

4. Konsep diri. Faktor lain yang menentukan kepribadian individu adalah konsep diri. Konsep diri sudah menjadi pendekatan yang dikenal amat luas untuk menggambarkan hubungan antara konsep diri konsumen dengan image merek. Bagaimana individu memandang dirinya akan mempengaruhi minat terhadap suatu objek. Konsep diri sebagai inti dari pola kepribadian akan menentukan perilaku individu dalam menghadapi permasalahan hidupnya, karena konsep diri merupakan frame of reference yang menjadi awal perilaku.

5. Motif. Perilaku individu muncul karena adanya motif kebutuhan untuk merasa aman dan kebutuhan terhadap prestise merupakan beberapa contoh tentang motif. Jika motif seseorang terhadap kebutuhan akan prestise itu besar maka akan membentuk gaya hidup yang cenderung mengarah kepada gaya hidup hedonis.

6. Persepsi adalah proses dimana seseorang memilih, mengatur, dan menginterpretasikan informasi untuk membentuk suatu gambar yang berarti mengenai dunia.

\section{b. Faktor Eksternal ${ }^{15}$}

1. Kelompok referensi. Kelompok referensi adalah kelompok yang memberikan pengaruh langsung atau tidak langsung terhadap sikap dan perilaku seseorang. Kelompok yang memberikan pengaruh langsung adalah kelompok dimana individu tersebut menjadi anggotanya dan saling berinteraksi, sedangkan kelompok yang memberi pengaruh tidak langsung adalah kelompok dimana individu tidak menjadi anggota didalam kelompok tersebut. Pengaruh-pengaruh tersebut akan menghadapkan individu pada perilaku dan gaya hidup tertentu.

2. Keluarga. Keluarga memegang peranan terbesar dan terlama dalam pembentukan sikap dan perilaku individu.Hal ini karena pola asuh orang tua akan membentuk kebiasaan anak yang secara tidak langsung mempengaruhi pola hidupnya.

3. Kelas sosial. Kelas sosial adalah sebuah kelompok yang relatif homogen dan bertahan lama dalam sebuah masyarakat, yang tersusun dalam sebuah urutan jenjang, dan para anggota dalam setiap jenjang itu memiliki nilai, minat, dan tingkah laku yang sama. Ada dua unsur pokok dalam sistem sosial pembagian kelas dalam masyarakat, yaitu kedudukan (status) dan peranan. Kedudukan sosial artinya tempat seseorang dalam lingkungan pergaulan, prestise hak-haknya serta kewajibannya. Kedudukan sosial ini dapat dicapai oleh seseorang dengan usaha yang sengaja maupun diperoleh karena kelahiran. Peranan merupakan aspek yang dinamis dari kedudukan. Apabila individu melaksanakan hak dan kewajibannya sesuai dengan kedudukannya maka ia menjalankan suatu peranan.

4. Kebudayaan. Kebudayaan yang meliputi pengetahuan, kepercayaan, kesenian, moral, hukum, adat istiadat, dan kebiasaan-kebiasaan yang diperoleh individu 
sebagai anggota masyarakat. Kebudayaan terdiri dari segala sesuatu yang dipelajari dari pola-pola perilaku yang normatif, meliputi ciri-ciri pola pikir, merasakan dan bertindak.

Setiap permasalahan timbul pasti karna ada faktor yang mengiringinya yang menyebabkan timbulnya sebuah permasalahan, begitu juga dengan masalah kemiskinan yang dihadapi oleh negara indonesia. Beberapa faktor yang menyebabkan timbulnya kemiskinan menurut Hartomo dan Aziz dalam Dadan Hudyana yang dikutif oleh Sarul Mardianto, yaitu: ${ }^{16}$

1. Pendidikan yang Terlampau Rendah.

Tingkat pendidikan yang rendah menyebabkan seseorang kurang mempunyai keterampilan tertentu yang diperlukan dalam kehidupannya. Keterbatasan pendidikan atau keterampilan yang dimiliki seseorang menyebabkan keterbatasan kemampuan seseorang untuk masuk dalam dunia kerja.

2. Malas Bekerja

Adanya sikap malas (bersikap pasif atau bersandar pada nasib) menyebabkan seseorang bersikap acuh tak acuh dan tidak bergairah untuk bekerja.

3. Keterbatasan Sumber Alam

Suatu masyarakat akan dilanda kemiskinan apabila sumber alamnya tidak lagi memberikan keuntungan bagi kehidupan mereka. Hal ini sering dikatakan masyarakat itu miskin karena sumberdaya alamnya miskin.

4. Terbatasnya Lapangan Kerja

Keterbatasan lapangan kerja akan membawa konsekuensi kemiskinan bagi masyarakat. Secara ideal seseorang harus mampu menciptakan lapangan kerja baru sedangkan secara faktual hal tersebut sangat kecil kemungkinanya bagi masyarakat miskin karena keterbatasan modal dan keterampilan.

5. Keterbatasan Modal

Seseorang miskin sebab mereka tidak mempunyai modal untuk melengkapi alat maupun bahan dalam rangka menerapkan keterampilan yang mereka miliki dengan suatu tujuan untuk memperoleh penghasilan.

6. Beban Keluarga

Seseorang yang mempunyai anggota keluarga banyak apabila tidak diimbangi dengan usaha peningakatan pendapatan akan menimbulkan kemiskinan karena semakin banyak anggota keluarga akan semakin meningkat tuntutan atau beban untuk hidup yang harus dipenuhi.

Suryadiningrat dalam Dadan Hudayana yang dikutif oleh Sarul Mardianto, ${ }^{17}$ juga mengemukakan bahwa kemiskinan pada hakikatnya disebabkan oleh kurangnya komitmen manusia terhadap norma dan nilai-nilai kebenaran ajaran agama, kejujuran dan keadilan. Hal ini mengakibatkan terjadinya penganiayaan manusia terhadap diri sendiri dan terhadap orang lain. Penganiayaan manusia terhadap diri sendiri tercermin dari adanya:

1. Keengganan bekerja dan berusaha. 
2. Kebodohan.

3. Motivasi rendah.

4. Tidak memiliki rencana jangka panjang.

5. Budaya kemiskinan.

6. Pemahaman keliru terhadap kemiskinan.

Sedangkan penganiayaan terhadap orang lain terlihat dari ketidakmampuan seseorang bekerja dan berusaha akibat:

1. Ketidakpedulian orang mampu kepada orang yang memerlukan atau orang tidak mampu.

2. Kebijakan yang tidak memihak kepada orang miskin.

Kemiskinan juga dapat disebabkan beberapa sumber dan proses penyebab terjadinya kemiskinan, yaitu:

1. Pelestarian Proses Kemiskinan. Proses pemiskinan yang dilestarikan, direproduksi melalui pelaksanaan suatu kebijakan diantaranya adalah kebijakan anti kemiskinan, tetapi realitanya justru melestarikan.

2. Pola Produksi Kolonial. Negara ekskoloni mengalami kemiskinan karena pola produksi kolonial, yaitu petani menjadi marjinal karena tanah yang paling subur dikuasai petani skala besar dan berorientasi ekspor.

3. Manajemen Sumber Daya Alam dan Lingkungan. Adanya unsur manajemen sumber daya alam dan lingkungan, seperti manajemen pertanian yang asal tebang akan menurunkan produktivitas.

4. Kemiskinan Terjadi Karena Siklus Alam. Misalnya tinggal di lahan kritis, dimana lahan ini jika turun hujan akan terjadi banjir tetapi jika musim kemarau akan kekurangan air, sehingga tidak memungkinkan produktivitas yang maksimal dan terus-menerus.

5. Peminggiran Kaum Perempuan. Dalam hal ini perempuan masih dianggap sebagai golongan kelas kedua, sehingga akses dan penghargaan hasil kerja yang diberikan lebih rendah dari laki-laki.

6. Faktor Budaya dan Etnik. Bekerjanya faktor budaya dan etnik yang memelihara kemiskinan seperti, pola hidup konsumtif pada petani dan nelayan ketika panen raya, serta adat istiadat yang konsumtif saat upacara adat atau keagamaan.

Faktor faktor penyebab kemiskinan dari hasil penelitian, diantaranya: ${ }^{18}$

\section{a. Tingkat Pendidikan Yang Ditamatkan Penduduk (EDU)}

Hasil penelitian Cameron $^{19}$ tentang kemiskinan di Jawa yang menyimpulkan bahwa pengurangan kemis-kinan diasosiasikan dengan meningkatnya pencapaian pendidikan dan peningkatan pendapatan dari tenaga kerja terdidik. Hasil penelitian Sukherman ${ }^{20}$ juga menunjukkan kemiskinan di Jawa Barat dipengaruhi oleh besarnya angka persentase angka melek huruf. Hasil penelitian lain yang berbeda dengan penelitian ini adalah hasil penelitian Niskanen $^{21}$ menunjukkan kemiskinan di AS menurun seiring meningkatnya pendidikan penduduk. Hal yang sama juga diperoleh dari hasil penelitian Islam ${ }^{22}$ yang dilakukan di 23 negara berkembang menunjukkan 
kemiskinan dapat berkurang seiring dengan meningkatnya pendidikan (menurunnya persentase buta huruf). Hasil penelitian ini juga berlawanan dengan hasil penelitian Balisacan et.al. ${ }^{23}$ yang menunjukkan bahwa tingkat pendidikan mempengaruhi kemiskinan. Dalam hal ini persentase orang dewasa yang bisa membaca dan menulis mempengaruhi pengurangan kemiskinan sebesar 0,129\%.

\section{b. Pendapatan Per Kapita Penduduk (PC)}

Hasil penelitian Iradian $^{24}$ yang dilakukan pada 82 negara untuk tahun 19652003. Hasil penelitian-nya menunjukkan bahwa tingginya pertumbuhan pendapatan per kapita tidak akan terlalu berdampak apabila tidak disertai dengan perbaikan dalam hal distribusi pendapatan. Peru-bahan pendapatan per kapita mempunyai pengaruh yang negatif terhadap kemiskinan. Hasil penelitian ini mengisyaratkan bahwa peningkatan pendapatan per kapita dan pertumbuhan ekonomi yang telah dicapai oleh Indonesia hanya dinikmati oleh sebagian kecil penduduk. Sementara sebagian besar penduduk yang saat ini hidup dalam kemiskinan tidak menikmati capai tersebut. Dengan kata lain meskipun ekonomi tumbuh dengan baik, tetapi mereka tetap berada dalam kemiskinan. Peningkatan kontra prestasi (gaji, honor, upah, dan bentuk lain) yang selama ini terjadi di Indonesia hanya dinikmati oleh sebagai orang. Peningkatan kontra prestasi tersebut tidak sampai menyentuh pada kelompok yang barada pada garis kemisikinan. Kondisi di atas juga sejalan dengan hasil penelitian Rifa' ${ }^{25}$ yang menunjukkan bahwa telah terjadi ketimpangan pendapatan di Kota Bandar Lampung dan Kota Metro Lampung. Dimana kenaikan pendapatan per kapita hanya dapat dinikmati oleh sebagian kecil penduduk di kedua kota tersebut. Sementara sebagian besar penduduk masih tetap dalam kondisi miskin karena tidak memiliki kemampuan untuk mengakses peningkatan pendapatan per kapita tersebut.

Namun demikian hasil penelitian ini berlawan dengan hasil peneltian Balisacan et.al. ${ }^{26}$ yang menunjukkan bahwa partumbuhan ekonomi mempengaruhi kemiskinan. Dalam hal ini pendapatan (standar hidup) orang miskin akan meningkat 7,74\% sejalan dengan kenaikan 10\% pendapatan pada tingkat kabupaten/kotamadya. Selain itu hasil penelitian Niskanen ${ }^{27}$ menunjukkan kemiskinan di AS menurun seiring meningkatnya pendapatan per kapita. Hasil penelitian ini juga berbeda dengan hasil penelitian Sukherman ${ }^{28}$ yang menunjukkan kemiskinan di Jawa Barat dipengaruhi oleh besarnya PDRB per kapita.

\section{c. Rasio Ketergantungan Penduduk}

Hasil penelitian ini sejalan dengan penelitian Rifa' ${ }^{29}$ yang menunjukkan kemiskinan di Kota Bandar Lampung dan Kota Metro Lampung dipengaruhi oleh rasio ketergantungan penduduk. Besarnya penduduk yang beraktifitas sebagai ibu rumah tangga, menganggur, dan sedang sekolah akan semakin memperbesar rasio ketergantungan penduduk di Kota Bandar Lampung dan Kota Metro. Apalagi hasil penelitian ini menunjukkan bahwa tingkat pendidikan tidak berpengaruh signifikan 
terhadap pengurangan faktor penyebab kemiskinan. Artinya jikalau nantinya penduduk yang saat ini sedang sekolah (SLTP/SMU/Diploma/Sarjana) telah lulus, maka kehadiran mereka tidak akan membantu mengurangi faktor penyebab kemiskinan. Tetapi kehadiran mereka justru akan menambah besar nilai rasio ketergantungan. Dengan kata lain kemungkinan mereka untuk menjadi pengangguran lebih besar karena sistem pendidikan yang ditenggarai tidak memiliki link and match dan miskin praktek/keterampilan.

Hasil penelitian ini juga sejalan dengan hasil penelitian Knowles ${ }^{30}$ yang menyatakan bahwa meningkatnya rasio ketergantungan akan meningkatkan proporsi populasi yang hidup dalam kemiskinan. Angka kelahiran yang tinggi berimplikasi pada tingginya rasio ketergantungan. Negara-negara berkembang di Asia yang sukses mengurangi angka kelahiran, maka rasio ketergantungannya relatif rendah. Selain itu juga hasil penelitian Islam ${ }^{31}$ yang dilakukan di 23 negara berkembang menunjukkan hasil yang sama yaitu kemiskinan akan meningkat seiring dengan meningkatnya rasio ketergantungan. Hasil penelitian Sukherman ${ }^{32}$ juga menunjukkan kemiskinan di Jawa Barat dipengaruhi oleh besarnya angka kematian bayi dan angka total fertilitas yang dapat memicu naikya angka rasio ketergantungan.

Faktor penyebab munculnya rasio ketergantungan adalah adanya tingkat kelahiran (fertilitas) yang tinggi. Word Bank (1978) ${ }^{33}$ menyatakan penyebab kemiskinan adalah adanya ledakan penduduk (population growth) yang tidak terkendali karena ledakan penduduk akan menyebabkan rasio ketergantungan (dependency ratio) yang tinggi. Sementara itu Malthus (1798) dalam Todaro ${ }^{34}$ menyatakan bahwa ledakan penduduk akan menimbulkan pola hidup yang serba paspasan (subsisten). Sedangkan pemikiran neo-Malthus menyatakan bangsa-bangsa yang miskin tidak akan pernah berhasil mencapai taraf hidup yang lebih tinggi dari tingkat subsisten, kecuali apabila mereka mengadakan pemeriksaan pengendalian preventif (preventive checks) terhadap pertumbuhan populasi mereka, atau dengan menerapkan pengendalian kelahiran. Nilai rata-rata total vertility rate (TVR) Indonesia tahun 2010 adalah 2,5. Artinya setiap keluarga memiliki tiga orang anak yang berarti dalam satu keluarga akan terdiri dari lima jiwa. Semakin besar jumlah anak maka semakin besar jumlah tanggungan yang harus di tanggung oleh kepala keluarga. Selanjutnya semakin besar jumlah penduduk yang berusia tidak produktif maka semakin besar tanggungan yang harus di tanggung oleh penduduk usia produktif.

\section{d. Pertumbuhan Ekonomi (GRW)}

Hasil penelitian World Bank (1990); Fields \& Jakobson (1989); Ravallion (1995) dalam Tambunan ${ }^{35}$ yang menyatakan bahwa tidak ada korelasi antara pertumbuhan ekonomi dengan tingkat kemiskinan. Pertumbuhan ekonomi yang tinggi tidak mampu mengurangi munculnya kemiskinan. Karena pertumbuhan ekonomi yang tinggi (growth oriented) justru hanya memicu munculnya kesenjangan 
pendapatan dan in-equality. Hal senada juga dihasilkan dalam penelitian Foster \& Szekely ${ }^{36}$ yang menyatakan bahwa pertumbuhan ekonomi tidak berpengaruh terhadap upaya menaikkan pendapatan penduduk miskin serta pertumbuhan ekonomi tidak bisa mengurangi gap pendapatan antara orang kaya dan orang miskin pada 185 rumah tangga dari 33 negara di Eropa, Amerika Latin, Asia, dan Kanada.

Hasil penelitian ini juga sejalan dengan penelitian Booth ${ }^{37}$ yang menunjukkan telah terjadi trade-off antara pertumbuhan ekonomi dan penurunan kemiskinan di Indonesia tahun 1985-1996 yang mengindikasikan telah terjadi ketimpangan dalam pemerataan hasil-hasil pembangunan di Indonesia pada kurun waktu tersebut. Selain itu hasil penelitian ini juga sejalan dengan penelitian Iradian ${ }^{38}$ yang dilakukan pada 82 negara untuk tahun 1965-2003. Hasil penelitian Iradian menunjukkan bahwa tingginya pertumbuhan pendapatan per kapita tidak akan terlalu berdampak apabila tidak disertai dengan perbaikan dalam hal distribusi pendapatan. Perubahan pendapatan per kapita mempunyai pengaruh yang negatif terhadap kemiskinan dan semakin besar ketimpangan distribusi pendapatan (gini ratio) maka semakin besar tingkat kemiskinan.

Pertumbuhan ekonomi yang tinggi yang selama ini dicapai oleh Indonesia ternyata tidak mampu mengurangi faktor penyebab kemiskinan. Kenaikan pertumbuhan ekonomi tersebut hanya bisa dinikmati oleh sebagian kecil orang di Indonesia. Efeknya akan memunculkan kemiskinan struktural dimana pertumbuhan ekonomi yang tinggi hanya bisa dinikmati oleh sebagian kecil orang kaya, sementara bagian terbesar masyarakat yang tetap miskin. Keadaan ini sesuai dengan teori "trade off between growth and equity" yang menyatakan bahwa pertumbuhan ekonomi yang tinggi akan menimbulkan ketimpangan yang semakin besar dalam pembagian pendapatan atau makin tidak merata, dan sebaliknya upaya pemerataan dapat terwujud dalam pertumbuhan ekonomi yang rendah.

Sebaliknya hasil penelitian ini berlawanan dengan hasil penelitian Balisacan et.al. ${ }^{39}$ yang menunjukkan bahwa pertumbuhan ekonomi mempengaruhi kemiskinan. Selain itu hasil penelitian ini juga berlawanan dengan pernyataan Bourguignon ${ }^{40}$ yang menjelaskan hubungan langsung yang mungkin terbentuk antara pembangunan, pertumbuhan dan distribusi pendapatan melalui teorinya "poverty-growth-inequality triangle". Ia menyatakan bahwa pengurangan kemiskinan di suatu negara dan di waktu tertentu ditentukan secara penuh oleh tingkat pertumbuhan ekonomi dan perubahan distribusi pendapatan. Hubungan ini sesuai dengan teori "tricle down effect" dimana bila ekonomi tumbuh, maka secara otomatis akan terjadi pemerataan hasil-hasil pembangunan atau "perembesan" ke bawah sehingga hasil-hasil pembangunan dapat dinikmati oleh kelompok miskin. Dengan demikian kaum miskin dapat keluar dari kemiskinannya.

Hasil penelitian ini juga berlawanan dengan pandangan Kuznets dalam $\mathrm{Wie}^{41}$ menjelaskan mengenai hubungan jangka panjang antara pertumbuhan ekonomi dan pemba-gian pendapatan yang menunjukkan bahwa proses pembangunan ekonomi 
pada tahap awal umumnya disertai oleh kemerosotan yang cukup besar dalam pembagian pendapatan, yang baru berbalik menuju suatu pemerataan yang lebih besar dalam pembagian pendapatan pada tahap pembangunan lebih lanjut. Hipotesis Kuznets ini berupa kurva $U$ terbalik dimana ketika pembangunan baru dimulai, distribusi pendapatan akan makin tidak merata (terjadi kemis-kinan), namun setelah mencapai suatu tingkat pembangunan tertentu, distribusi pendapatan semakin merata (kemakmuran).

\section{e. Persentase Tenaga Kerja Di Sektor Pertanian (TKP)}

Hasil penelitian Booth ${ }^{42}$ yang menunjukkan bahwa kemiskinan di pedesaan di Indonesia dapat berkurang dengan meningkatkan nilai tambah hasil pertanian. Sehingga pembangunan pedesaan dan pertanian, dimana ada kenaikkan produktivitas per hektar atau pada rumah tangga, seharusnya diprio-ritaskan untuk bagian pulau di luar Jawa dan Bali dimana kemiskinan tinggi. Persentase tenaga kerja di sektor pertanian tidak mampu mengurangi factor penyebab kemiskinan karena sektor ini secara umum ditenggarai memiliki produktifitas rendah, kelebihan tenaga kerja, upah yang rendah, dan bersifat subsisten. Selain itu penelitian Ritonga ${ }^{43}$ juga menyatakan bahwa penduduk miskin di Indonesia pada umumnya bekerja di sektor pertanian dan mempunyai tingkat pendidikan SD ke bawah. Oleh karena itu program pengentasan kemiskinan di sektor pertanian perlu diprioritaskan. Pembangunan sektor pertanian melalui revitalisasi pertanian, perikanan, dan kehutanan serta pembangunan masyarakat pedesaan perlu menjadi pijakan untuk membawa masyarakat Indonesia keluar dari permasalahan kemiskinan.

Namun demikian hasil penelitian ini berlawanan dengan hasil penelitian Rifa'i, $\mathrm{dkk}^{44}$ yang menunjukkan bahwa produktivitas tenaga kerja usaha kecil yang bergerak di sektor pertanian lebih rendah jika dibandingkan dengan produktifitas tenaga kerja usaha kecil yang bergerak di sektor industri. Sehingga kehadiran tenaga kerja di sektor pertanian tidak mampu mengurangi faktor penyebab munculnya kemiskinan di Provinsi Lampung. Sementara itu Kuntjoro ${ }^{45}$ menyatakan sebuah negara miskin karena menggantungkan diri pada sektor pertanian yang subsisten, metode produksi yang tradisional, dan seringkali dibarengi dengan sikap apatis terhadap lingkungan. Sektor pertanian dianggap sebagai sektor pemicu kemiskinan karena, seperti dinyatakan oleh Lewis dalam Todaro, ${ }^{46}$ sektor pertanian merupakan sektor subsisten yang kelebihan penduduk dan produktivitas marjinal tenaga kerjanya hampir sama dengan nol.

Hasil penelitian lain berlawanan dengan hasil penelitian ini adalah penelitian Islam $^{47}$ yang dilakukan di 23 negara berkembang menunjukkan kemiskinan akan meningkat seiring dengan meningkatnya persentase tenaga kerja di sektor pertanian. Hasil yang sama juga diperoleh dari penelitian Suryahadi dan Sumarto ${ }^{48}$ yang menyatakan bahwa sektor pertanian adalah salah satu sumber kemiskinan dan daya tahan sektor ini lebih rentan terhadap krisis ekonomi. Hal yang sama juga dinyatakan 
oleh Skoufias ${ }^{49}$ yang menyatakan bahwa konsumsi tenaga kerja sektor industri lebih besar dari konsumsi tenaga kerja sektor pertanian. Hal ini mengindikasikan bahwa pendapatan pekerja usaha kecil yang bekerja disektor industri non pertanian lebih besar daripada penghasilan tenaga kerja usaha kecil yang bekerja disektor industri yang bergerak disektor pertanian. Fakta ini secara tidak langsung menunjukkan bahwa produktivitas tenaga kerja usaha kecil yang bergerak di sektor pertanian lebih rendah jika dibandingkan dengan produktifitas tenaga kerja usaha kecil yang bergerak di sektor industri.

\section{f. Persentase Tenaga Kerja Di Sektor Industri (TKI)}

Hasil penelitian Cameron ${ }^{50}$ yang menyatakan bahwa pengurangan kemiskinan di Jawa diasosiasikan dengan meningkatnya peningkatan pendapatan dari tenaga kerja terdidik dan pendapatan yang didapat pekerja di luar pertanian (sektor industri). Penelitian lain yang sejalan dengan penelitian ini adalah hasil penelitian Sukherman ${ }^{51}$ menunjukkan kemiskinan di Jawa Barat dipengaruhi oleh besarnya angka kontribusi sektor industri terhadap perekonomian regional. Hasil penelitian Islam $^{52}$ yang dilakukan di 23 negara berkembang juga menunjukkan kemiskinan dapat berkurang seiring dengan meningkatnya persentase tenaga kerja di sektor industri.

Peran penting sektor industri dalam mengurangi faktor penyebab kemiskinan salah satunya ditunjukkan oleh hasil penelitian Skoufias ${ }^{53}$ yang menyatakan bahwa konsumsi tenaga kerja sektor industri lebih besar dari konsumsi tenaga kerja sektor pertanian. Hal ini mengindikasikan bahwa pendapatan pekerja usaha kecil yang bekerja disektor industri non pertanian lebih besar daripada penghasilan tenaga kerja usaha kecil yang bekerja disektor industri yang bergerak disektor pertanian. Secara umum jika seseorang yang bekerja di sektor industri memiliki tingkat konsumsi yang tinggi, maka sudah dapat dipastikan pendapatannya akan cenderung tinggi. Karena pada umumya tingkat konsumsi akan tetap berada di bawah pendapatan. Jika jika konsumsi seseorang tinggi, maka pendapatanya juga akan tinggi. Jika pendapatan seseorang tinggi, maka upaya pengurangan faktor penyebab kemiskinan akan semakin mudah diwujudkan.

\section{B. Dampak Kemiskinan}

Kemiskinan pada akibatnya memiliki dampak bagi orang yang menyandangnya, beberapa dampak atau akibat dari kemiskinan, di antaranya:

1. Pengangguran

Pengangguran merupakan dampak dari kemiskinan, berhubung pendidikan dan keterampilan merupakan hal yang sulit diraih masyarakat, maka masyarakat sulit untuk berkembang dan mencari pekerjaan yang layak untuk memenuhi kebutuhan. Dikarenakan sulit untuk bekerja, maka tidak adanya pendapatan membuat pemenuhan kebutuhan sulit, kekurangan nutrisi dan kesehatan, dan tak dapat memenuhi kebutuhan penting lainnya. Misalnya saja harga beras yang semakin meningkat, 
orang yang pengangguran sulit untuk membeli beras, maka mereka makan seadanya. Seorang pengangguran yang tak dapat memberikan makan kepada anaknya akan menjadi dampak yang buruk bagi masa depan sehingga akan mendapat kesulitan untuk waktu yang lama.

Jumlah penganggur di Banten tahun 2013 ini mengalami kenaikan menjadi 552 ribu jiwa, dari 519 ribu jiwa pada tahun 2012. Kenaikan jumlah penganggur itu berasal dari lulusan SMA sederajat dan perguruan tinggi tahun ini. "Untuk satu tahun lulusan terdapat sekitar ratusan ribu penganggur baru dari segala tingkatan. Sementara peluang kerja yang tersedia cenderung tidak bertambah. Untuk mengatasi jumlah penganggur yang memiliki kecenderungan terus meningkat dalam setiap tahunnya Dinas Tenaga Kerja dan Transmigrasi Pemprov Banten terus melakukan upaya-upaya untuk menekannya. Salah satunya, yang dilaksanakan adalah penyelenggaraan bursa kerja secara terbuka. Juga dalam bursa kerja berbagai perusahaan, baik besar maupun kecil akan menawarkan lowongan kerja di perusahaannya masing-masing..$^{54}$

Sementara itu data Badan Pusat Statistik (BPS) Provinsi Banten bahwa jumlah angkatan kerja per Februari 2013 mencapai 5.475.876 orang, atau bertambah sebesar 77.232 orang, dibandingkan pada Februari 2012 yang sebesar 5.398.644 orang. Adapun jumlah penduduk bekerja, per Februari 2013 adalah 4.922.981 orang, atau bertambah 104.014 orang dibandingkan pada Februari 2012. Dengan begitu jumlah pengangguran terbuka mengalami penurunan sebesar 26.782 orang, atau disebut Tingkat Pengangguran Terbuka (TPT) turun dari 10,74 persen menjadi 10,10 persen. Pada kurun waktu tersebut, BPS mencatat, hampir semua sektor usaha mengalami kenaikan jumlah pekerja, dengan sector usaha yang melakukan penyerapan tenaga kerja terbanyak adalah perdagangan, yakni menyerap sebesar 1.243 .486 orang, atau 25,25 persen dari penduduk yang bekerja. ${ }^{55}$

Pengganguran berdampak negatif terhadap kegiatan perekonomian, seperti:

a. Pendapatan nasiomal riil (nyata) yang dicapai oleh masyarakat lebih rendah dari pada pendapatan potensial (pendapatan yang seharusnya). Sehingga kemakmuran yang dicapai masyarakat pun lebih rendah.

b. Pengangguran menyebabkan kegiatan perekonomian menurun sehingga kegiatan pembangunan pun akan terus menurun.

c. Tingkat kemakmuran yang dapat dinikmati masyarakat lebih rendah daripada tingkat kemakmuran yang mungkin dicapainya.

d. Berkurangnya investor untuk melakukan perluasan dan pendirian industri baru. Sehingga, tingkat investasi turun sehingga pertumbuhan ekonomi pun tidak meningkat.

e. Menambah beban pengeluaran negara.

f. Menimbulkan ketidakstabilan politik. 
g. Jumlah penduduk miskin semakin bertambah yang berarti beban pemerintah dalam upaya pengentasan kemiskinan kian terasa berat.

h. Dapat menyebabkan kehilangan kepercayaan diri dan menimbulkan perselisihan dalam keluarga.

2. Kriminalitas

Kriminalitas merupakan dampak lain dari kemiskinan. Kesulitan mencari nafkah mengakibatkan orang lupa diri sehingga mencari jalan cepat tanpa memedulikan halal atau haramnya uang sebagai alat tukar guna memenuhi kebutuhan. Misalnya saja perampokan, penodongan, pencurian, penipuan, pembegalan, penjambretan dan masih banyak lagi contoh kriminalitas yang bersumber dari kemiskinan. Mereka melakukan itu semua karena kondisi yang sulit mencari penghasilan untuk keberlangsungan hidup dan lupa akan nilai-nilai yang berhubungan dengan Tuhan. Di era global dan materialisme seperti sekarang ini tak heran jika kriminalitas terjadi di mana pun.

\section{Putus Sekolah}

Putusnya sekolah dan kesempatan pendidikan sudah pasti merupakan dampak kemiskinan. Mahalnya biaya pendidikan menyebabkan rakyat miskin putus sekolah karena tak lagi mampu membiayai sekolah. Putus sekolah dan hilangnya kesempatan pendidikan akan menjadi penghambat rakyat miskin dalam menambah keterampilan, menjangkau cita-cita dan mimpi mereka. Ini menyebabkan kemiskinan yang dalam karena hilangnya kesempatan untuk bersaing dengan global dan hilangnya kesempatan mendapatkan pekerjaan yang layak.

\section{Kesehatan}

Kesehatan sulit untuk didapatkan karena kurangnya pemenuhan gizi sehari-hari akibat kemiskinan membuat rakyat miskin sulit menjaga kesehatannya. Belum lagi biaya pengobatan yang mahal di klinik atau rumah sakit yang tidak dapat dijangkau masyarakat miskin. Ini menyebabkan gizi buruk atau banyaknya penyakit yang menyebar.

\section{Buruknya generasi penerus}

Buruknya generasi penerus adalah dampak yang berbahaya akibat kemiskinan. Jika anak-anak putus sekolah dan bekerja karena terpaksa, maka akan ada gangguan pada anak-anak itu sendiri seperti gangguan pada perkembangan mental, fisik dan cara berfikir mereka. Contohnya adalah anak-anak jalanan yang tak mempunyai tempat tinggal, tidur dijalan, tidak sekolah, mengamen untuk mencari makan dan lain sebagainya. Dampak kemiskinan pada generasi penerus merupakan dampak yang panjang dan buruk karena anak-anak seharusnya mendapatkan hak mereka untuk bahagia, mendapat pendidikan, mendapat nutrisi baik dan lain sebagainya. Ini dapat 
menyebabkan mereka terjebak dalam kesulitan hingga dewasa dan berdampak pada generasi penerusnya.

\section{Cara Menanggulangi Kemiskinan}

Berbagai cara yang dilakukan pemerintah dalam menanggulangi kemiskinan, berikut ini akan penulis paparkan, yaitu:

\section{a. Melaui PNPM Mandiri}

PNPM Mandiri adalah program nasional penanggulangan kemiskinan terutama yang berbasis pemberdayaan masyarakat. Pengertian yang terkandung mengenai PNPM Mandiri adalah: ${ }^{56}$

1. PNPM Madiri adalah program nasional dalam wujud kerangka kebijakan sebagai dasar dan acuan pelaksanaan program-program penanggulangan kemiskinan berbasis pemberdayaan masyarakat. PNPM Mandiri dilaksanakan melalui harmonisasi dan pengembangan sistem serta mekanisme dan prosedur program, penyediaan pendampingan dan pendanaan stimulan untuk mendorong prakarsa dan inovasi masyarakat dalam upaya penanggulangan kemiskinan yang berkelanjutan.

2. Pemberdayaan masyarakat adalah upaya untuk menciptakan/meningkatkan kapasitas masyarakat, baik secara individu maupun berkelompok, dalam memecahkan berbagai persoalan terkait upaya peningkatan kualitas hidup, kemandirian dan kesejahteraannya. Pemberdayaan masyarakat memerlukan keterlibatan yang besar dari perangkat pemerintah daerah serta berbagai pihak untuk memberikan kesempatan dan menjamin keberlanjutan berbagai hasil yang dicapai.

Sedangkan tujuan yang ingin dicapai dalam pelaksanaan Program PNPM Mandiri ini adalah:

1. Tujuan Umum

Meningkatnya kesejahteraan dan kesempatan kerja masyarakat miskin secara mandiri.

\section{Tujuan Khusus}

Meningkatnya partisipasi seluruh masyarakat, termasuk masyarakat miskin, kelompok perempuan, komunitas adat terpencil dan kelompok masyarakat lainnya yang rentan dan sering terpinggirkan ke dalam proses pengambilan keputusan dan pengelolaan pembangunan.

Meningkatnya kapasitas kelembagaan masyarakat yang mengakar, representatif dan akuntabel.

Meningkatnya kapasitas pemerintah dalam memberikan pelayanan kepada masyarakat terutama masyarakat miskin melalui kebijakan, program dan penganggaran yang berpihak pada masyarakat miskin (pro-poor)

Meningkatnya sinergi masyarakat, pemerintah daerah, swasta, asosiasi, perguruan tinggi, lembaga swadaya masyarakat, organisasi masyarakat dan kelompok perduli lainnya untuk mengefektifkan upaya-upaya penanggulangan kemiskinan. 
Meningkatnya keberadaan dan kemandirian masyarakat serta kapasitas pemerintah daerah dan kelompok perduli setempat dalam menanggulangi kemiskinan di wilayahnya.

Meningkatnya modal sosial masyarakat yang berkembang sesuai dengan potensi sosial dan budaya serta untuk melestarikan kearifan lokal.

Meningkatnya inovasi dan pemanfaatan teknologi tepat guna, informasi dan komunikasi dalam pemberdayaan masyarakat.

PNPM Mandiri dapat dikategorikan atas:

1. PNPM-Inti: terdiri dari program/kegiatan pemberdayaan masyarakat berbasis kewilayahan, seperti PNPM Perdesaan (PPK), PNPM Perkotaan (P2KP), PNPM Daerah tertinggal dan Khusus (P2DTK), PNPM Infrastruktur Perdesaan (PPIP), dan PNPM Infrastruktur Sosial Ekonomi Wilayah (PISEW).

2. PNPM-Penguatan: terdiri dari program-program pemberdayaan masyarakat berbasis sektoral, kewilayahan, serta khusus untuk mendukung penanggulangan kemiskinan yang pelaksanaannya terkait pencapaian target tertentu. Termasuk dalam PNPM Penguatan adalah Program Pengembangan Usaha Agribisnis Pedesaan (PUAP), Bantuan Langsung Masyarakat untuk Keringanan Investasi Pertanian (BLM-KIP) dan sebagainya. Harmonisasi melalui PNPM akan dilaksanakan hingga tahun 2015, sejalan dengan target MDGs. Rentang waktu yang cukup panjang ini diharapkan akan menghasilkan modal kemandirian di daerah agar keberlanjutan dalam bentuk program lain setelah program ini selesai dan dapat diwujudkan.

\section{b. Program Perumahan}

Pemenuhan kebutuhan perumahan bagi masyarakat miskin tertuang dalam Peraturan Presiden RI No 7 Tahun 2005 tentang Rencana Pembangunan Jangka Menengah Nasional dimana diungkapkan bahwa dalam pemenuhan hak masyarakat miskin atas perumahan yang layak dan sehat dilakukan dengan: ${ }^{57}$

1. Mengembangkan partisipasi masyarakat dalam penyediaan perumahan.

2. Menyempurnakan peraturan perundangundangan yang dapat menjamin perlindungan hak masyarakat miskin atas perumahan.

3. Meningkatkan pengetahuan dan kemampuan masyarakat dalam pembangunan rumah yang layak dan sehat.

4. Meningkatkan keterjangkauan (affordability) masyarakat miskin terhadap perumahan yang layak dan sehat, dan

5. Meningkatkan ketersediaan rumah yang layak dan sehat bagi masyarakat miskin dan golongan rentan.

Di sisi lain upaya pemerintah dalam menanggulangi kemiskinan melalui pemenuhanperumahan bagi masyarakat miskin juga tertuang dalam Strategi Nasional Penanggulangan Kemiskinan. Dalam strategi ini diungkapkan bahwa kebijakan pemenuhan hak atas perumahan ditujukan untuk memenuhi hak masyarakat miskin 
atas tempat tinggal atau perumahan yang layak dan lingkungan permukiman yang sehat. Adapun kebijakan tersebut adalah:

1. Menyediakan rumah yang layak dan sehat yang terjangkau bagi masyarakat miskin baik laki-laki maupun perempuan.

2. Meningkatkan partisipasi masyarakat dalam pengembangan dan penyediaan rumah yang layak dan sehat.

3. Meningkatkan perlindungan terhadap lingkungan permukiman dan perumahan rakyat terutama komunitas adat. Berdasarkan kedua kebijakan yang ditetapkan pemerintah untuk penanggulangan kemiskinan dalam bidang perumahan dan permukiman terlihat bahwa peran serta masyarakat merupakan hal penting dalam penyediaan perumahan dan permukiman tersebut. Peran serta ini juga diungkapkan oleh Siswono Yudohusodo jauh sebelum kebijakan ini diundangkan dan direncanakan pemerintah.

\section{c. Program Layanan Kesehatan}

Sebagai salah satu upaya untuk pengentasan kemiskinan, pemerintah melalui Kementerian Kesehatan sejak tahun 2005 membuat Program Jaminan Kesehatan bagi Masyarakat miskin dan tidak mampu yang disebut dengan program Askeskin. Pengelolaan Program Askeskin yang dilaksanakan oleh PT Askes (Persero) merupakan penugasan dari Pemerintah berdasarkan Surat Keputusan Menteri Kesehatan nomor : 1241/MENKES/SK/XI/2004. Sebagai BUMN, penugasan tersebut dilaksanakan dengan mengacu pada pasal 66 UU nomor 19 tahun 2003 tentang BUMN dan telah mendapatkan persetujuan Menteri Negara BUMN dengan Surat Persetujuan Meneg BUMN Nomor S-697/HBU/2004 tanggal 31 Desember 2004. ${ }^{58}$

Pasal 33 UUD Negara RI Tahun 1945 mengamanatkan penyelenggaraan jaminan sosial bagi seluruh rakyat. Pasal 34 ayat $(2)^{59}$ juga mengamanatkan bahwa negara mengembangkan sistem jaminan sosial bagi seluruh rakyat dan memberdayakan masyarakat yang lemah dan tidak mampu, sesuai dengan martabat kemanusiaan. Kemudian Pasal 28 H UUD Negara RI Tahun 1945 dan UU No. 23 Tahun 1992 tentang Kesehatan, menetapkan bahwa setiap orang berhak mendapatkan pelayanan kesehatan. Karena itu setiap individu, keluarga dan masyarakat berhak memperoleh perlindungan terhadap kesehatannya, dan negara bertanggung jawab mengatur agar terpenuhi hak hidup sehat bagi penduduknya termasuk bagi masyarakat miskin dan tidak mampu.

\section{d. Program Pendidikan}

Pendidikan merupakan salah satu faktor utama untuk dapat mencapai kemakmuran suatu negara, sebagaimana diatur secara tegas dalam pasal 31 ayat (1) Undang Undang Dasar 1945 (UUD 1945) yang menyatakan bahwa setiap warga negara berhak mendapat pendidikan. Ayat (2) menegaskan bahwa setiap warga negara wajib mengikuti pendidikan dasar dan pemerintah wajib membiayainya. Ayat 
(3) menetapkan bahwa Pemerintah mengusahakan dan menyelenggarakan suatu sistem pendidikan nasional, yang meningkatkan keimanan dan ketaqwaan serta akhlak mulia dalam rangka mencerdaskan kehidupan bangsa, yang diatur dengan undang-undang. Sedangkan ayat (4) menugaskan negara untuk memprioritaskan anggaran pendidikan sekurang-kurangnya 20 persen dari anggaran pendapatan dan belanja negara (APBN) serta dari anggaran pendapatan daerah (APBD) untuk mememenuhi kebutuhan penyelenggaraan pendidikan nasional.

Pengejawantahan dari Undang-Undang Dasar 1945 (UUD 1945) yang dilakukan dengan program bidikmisi. Bidik Misi adalah program bantuan biaya pendidikan yang diberikan Pemerintah melalui Direktorat Jenderal Pendidikan Tinggi (Ditjen Dikti) Kementerian Pendidikan dan Kebudayaan mulai tahun 2010 kepada mahasiswa yang memiliki potensi akademik memadai dan kurang mampu secara ekonomi. Bidik Misi merupakan program 100 Hari Kerja Menteri Pendidikan Nasional yang dicanangkan pada tahun 2010. Perguruan tinggi yang mendapat bantuan Bidik Misi yaitu perguruan tinggi di bawah Kementerian Pendidikan dan Kebudayaan dan Kementerian Agama.

\section{Kesimpulan}

Dari uraian di atas dalam pembahasan ini dapat disimpulkan, yaitu bahwa penyebab kemiskinan adalah: 1). Faktor internal, dipengaruhi oleh sikap, pengalaman dan pengamatan, kepribadian, konsep diri, motif dan persepsi. 2). Faktor eksternal, dipengaruhi oleh kelompok referensi, keluarga, kelas sosial, dan budaya. Kemudian dampak dari kemiskinan tersebut dapat mengakibatkan pengangguran, kriminalitas, kesehatan, putus sekolah dan buruknya generasi penerus.

Untuk menanggulangi kemiskinan, sebaiknya pemerintah mengeluarkan kebijakan untuk memenuhi penyebab dan dampak dari kemiskinan tersebut yaitu berupa pemenuhan hak penduduk atas sandang dan pangan, memperoleh rumah layak huni, jaminan kesehatan dan pendidikan gratis bagi rakyat miskin. Dengan programprogram tersebut sedikit demi sedikit kemiskinan dapat diminimalisir.

\section{Catatan Akhir:}

\footnotetext{
${ }^{1}$ Mohammad Ali, Kamus Lengkap Bahasa Indonesia Modern (Jakartta: Penerbit Pustaka Amani, t.t. ), hal. 255.

${ }^{2}$ Soekanto S, Sosiologi Suatu Pengantar, (Jakarta: PT Raja Grafindo Persada, 1990).

${ }^{3}$ Anonymous, Petunjuk Teknis Operasional PNPM Mandiri Pedesaan, Departemen Dalam Negeri Direktorat Pemberdayaan Masyarakat dan Desa (Jakarta: 2008), hal. 2.

${ }^{4}$ Gunawan Sumodiningrat, Budi Santoso, Mohammad Maiwan, Kemiskinan: Teori, Fakta dan Kebijakan, (Jakarta: IMPAC, 1998), hal. 43.
} 
${ }^{5}$ Moeljarto Tjokrowinoto, Pengembangan Kawasan dan Pengentasan Kemiskinan dalam buku Liberalisasi Ekonomi, Pemerataan dan Kemiskinan, (Yogyakarta: PT. Tiara Wacana Yogya, 199), hal. 85 .

${ }^{6}$ Sri Mulyani, Dialog Tentang Kemiskinan Pasca Kenaikan BBM, Selasa tgl. 8 Maret 2005, jam 21.00 WIB. di SCTV. Sri Mulyani adalah sebagai mentri perekonomian pada kabinet bersatu priode 20042009. Masa pemerintahan Susilo Bambang Yudoyono (SBY) dan Jusuf Kala (JK).

${ }^{7}$ Abdurrahman Al-Jaziri, Kitabul Fiqh 'Alal Mazdahibil Arba'ah, (Beirut: Daar El-Fikr, 1994), hal. 506.

${ }^{8}$ Muhammad Jawad Mugniyah, al-Fiqh ala 'al-Madzahib al-Khomsah, (Beirut: Daar El-Fikr, 1996), hal. 191.

${ }^{9}$ Gunawan Sumodiningrat, Penanggulangan Kemiskinan Melalui Kredit Pedesaan, Seri Kajian Fiskal dan Moneter No.5, (Jakarta: PT. Bina Rena Pariwara Cetakan ke 2, 1996), hal.7.

${ }^{10}$ Seri Kajian Fiskal dan Moneter No. 6/VII/96 Strategi dan Evaluasi Mengentaskan Kemiskinan, Cetakan ke 2 (Jakarta: PT. Bina Rena Pariwara, 1996), hal. 44-47.

${ }^{11}$ Dalil Hasan, Bentuk Pengorganisasian yang Cocok untuk Mengembangkan Potensi Golongan Ekonomi Lemah dan Mengentaskan Kemiskinan, (Jakarta: PT. Bineka Rena Pariwara, 1996), hal. 7.

${ }^{12}$ Kuncoro, yang dikutip oleh Anonymous, "Pengertian Kemiskian dampak akibat dan solusinya" Artikel, http://imanarsyad.blogspot.com/2012/03/pengertian-kemiskian-dampak-akibat-dan.html, di akses 13-9-2013.

${ }^{13}$ Anonymous, "Kemiskinan" Artikel, http://id.wikipedia.org, diakses 13-9-2013.

${ }^{14}$ Anonymous, "Kemiskinan", Artkel, http://blog.dunixi.com, diakses 13-9-2013.

${ }^{15}$ Nugraheni, dikutip oleh Anonymous, "Kemiskinan", Artkel, http://blog.dunixi.com, diakses 13-92013.

${ }^{16}$ Sarul Mardianto, "Kemiskinan di Indonesia" Universitas Syiah Kuala, t.t.

17 Ibid.

${ }^{18}$ Sigit Prasetyo, "Studi Faktor Penyebab Kemiskinan dan Mekanisme Penanggulangan Kemiskinan di Indonesia", Makalah, Magister Ilmu Ekonomi Fakultas Ilmu Ekonomi dan Bisnis Universitas Lampung 2013.

${ }^{19}$ Cameron, Lisa A, Poverty and Inequality in Java: Examining the Impact of The Changing Age, Educational, and Industrial Structure, Journal of Development Economics, Vol. 62 (2000).

${ }^{20}$ Maman Sukherman, Assosiasi Kemiskinan Dengan Peubah Sosek di Propinsi Jawa Barat, Jurnal Kependudukan Padjadjaran. Vol. 3, No. 1, Januari 2001, hal, 47-64.

${ }^{21}$ William A Niskanen, Welfare and Culture of Poverty. The Cato Jurnal, Vol. 16, No. 1.

${ }^{22}$ Rizwatul Islam, The Nexus of Economic Growth, Employment and Poverty Reduction An Empirical Analysis. Report on Seminar on Accelerating Growth and Poverty Reduction in Bangladesh. ILO, Geneva, 2003.

${ }^{23}$ A. Balisacan, \& Pernia, E. \& Asra, A, Revisiting, Growth and Poverty Reduction in Indonesia: What Do Subnational Data Show?. Bulletin of Indonesian Economics Studies, Vol 39. No. 3, 2003.

24 Garbis Iradian, Inequality, Poverty, and Growth: Cross Country Evidence. IMF Working Paper. Middle East and Central Asia Departement, 2005.

${ }^{25}$ Sigit Prasetyo, Ahmad Rifa'i, Deddy Aprilani, Strategi-Bisnis Usaha Kecil Di Bandar Lampung, Laporan Penelitian Hibah PDM Dikti November 2007.

${ }^{26}$ Balisacan, A. loc. cit.

${ }^{27}$ William A. Niskanen, loc. cit.

${ }^{28}$ Maman Sukherman, loc. cit.

${ }^{29}$ Sigit Prasetyo, loc. cit.

${ }^{30}$ James C Knowles, A Look at Poverty in The Developing Countries of Asia. Asia-Pacific Population \& Policy, No. 52, January 2002.

${ }^{31}$ Rizwatul Islam, loc. cit. 
${ }^{32}$ Maman Sukherman, loc. cit.

33 World Bank, Poverty Headcount Ratio at National Poverty Line (\% of Population). http://data.worldbank.org/indicator/SI.POV.NAHC, 2012.

${ }^{34}$ Michael P Todaro, Pembangunan Ekonomi di Dunia Ketiga, Edisi Ketujuh, Jilid I. Terjemahan Haris Munandar, (Jakarta: Erlangga, 2000).

35 Tulus T.H. Tambunan, Transformasi Ekonomi Di Indonesia, (Jakarta: Salemba Empat, 2001).

${ }^{36}$ James E. Foster dan Miguel Szekely, Is Economic Growth Good for the Poor? Tracking Low Incomes Using General Means. Report on Symposium on Poverty Measurement, Mexico, 2002.

${ }^{37}$ Anne Booth, Poverty and Inequality in the Soeharto Era: An Assesment. Bulletin of Indonesian Economics Studies, Vol.36, No.1, 2000.

${ }^{38}$ Garbis Iradian, loc. cit.

${ }^{39}$ Ibid.

${ }^{40}$ Francois Bourguignon, The Poverty-Growth-Inequality Triangle. Report on Indian Council For Research on International Eco Relations, New Delhi, 2004.

${ }^{41}$ Thee Kian Wie, Pembangunan Ekonomi dan Pemerataan, Beberapa Pendekatan Alternatif. Jakarta: LP3ES, 1983.

${ }^{42}$ Anne Booth, loc. cit.

${ }^{43}$ Hamonangan Ritonga, Perkembangan Indikator Kemiskinan dan Ketena-gakerjaan Tahun 2004 dan Perkiraan Tahun 2005-2006. Journal of Quarterly Review of The Indonesian Economy, Vol 7 (1). Januari 2006, hal. 17-31.

${ }^{44}$ Deddy Aprilani, Ahmad Rifa'i, Pengaruh Jiwa Wirausaha dan Manajemen Usaha Terhadap Keberhasilan Usaha (Studi pada UMKM di Bandar Lampung), Laporan Penelitian Hibah DIPA PNBP Unila November 2007.

${ }_{45}$ Mudrajad Kuntjoro, Ekonomi pembangunan, Teori, Masalah, dan Kebijakan, Edisi Ketiga. Yogyakarta: UPP AMP YKPN, 2003.

${ }^{46}$ Michael P. Todaro, Pembangunan Ekonomi di Dunia Ketiga, Edisi Ketujuh, Jilid I. Terjemahan Hasris Munandar. Jakarta: Erlangga, 2000.

${ }^{47}$ Rizwatul Islam, loc. cit.

${ }^{48}$ Asep Suryahadi, dan Sudarno Sumarto, 2003. Poverty and Vulnerability in Indonesia Before and After Economic Crisis. Asian Economic Journal. Vol 17 No. 1, hal. 45-64.

${ }^{49}$ Emmanuel Skoufias, Changes in Houshold Welfare, Poverty and Inequality During The Crisis. Bulletin of Indonesian Economic Studies. Vol 36 No. 2 Augustus, 2000, hal. 97-144.

${ }^{50}$ Lisa A. Cameron, loc. cit.

${ }^{51}$ Maman Sukherman, loc. cit.

${ }_{53}^{52}$ Rizwatul Islam, loc. cit.

${ }^{53}$ Emmanuel Skoufias, loc. cit.

${ }^{54}$ Erik Syehabudin, dalam Banten POS, diakses 14-6-2013.

${ }_{56}^{55}$ Banten dalam Angka, BPS Provinsi Banten Tahun 2012.

${ }^{56}$ PNPM Mandiri "Penjelasan dan Tanya Jawab Seputar Program Nasional Pemberdayaan Masyarakat (PNPM) Madiri” Pedoman, Tim Pengendali PNPM Mandiri, Tahun 2010, hal. 2

${ }^{57}$ I Dewa Gede Agung Diasana Putra dan Anak Agung Gde Yana, "Pemenuhan Atas Perumahan Salah Satu Upaya Penanggulangan Kemiskinan" Jurnal Permukiman Natah, Vol. 5 No. 2 Agustus 2007.

${ }^{58}$ Sumber PT. Askes (Persero) Indonesia, 2013.

${ }^{59}$ UUD 1945 Tahun 2013. 


\section{DAFTAR PUSTAKA}

AG, Pringgodigdo, Tatanegara di Jawa Pada Waktu Penduduk Jepang dari Bulan Maret-Desember 1942, Yayasan Post Universitet, Negeri Gajah Mada, tt.

Al-Jaziri, Abdurrahman, Kitabul Fiqh 'Alal Mazdahibil Arba'ah, Beirut: Daar ElFikr, 1994.

Ali, Mohammad, Kamus Lengkap Bahasa Indonesia Modern, Jakartta: Penerbit Pustaka Amani, t.t.

Amalia, Euis, Keadilan Distributif dalam Ekonomi Islam: Penguatan Peran LKM dan UKM di Indonesia, Jakarta: PT. Raja Grafindo Persada, 2001

--------, Reformasi Kebijakan Bagi Penguatan Peran Lembaga Keuangan Mikro dan Usaha Kecil Mikro di Indonesia (Analisis Keadilan Distributif dalam Ekonomi Islam),UIN Syarif Hidayatullah Jakarta, 2008.

Anonymous, Pedoman Umum Program Nasional Pemberdayaan Masyarakat (PNPM) Mandiri, Ditjen PMD Departemen Dalam Negeri, Jakarta: 2007).

-------, Tanya Jawab Seputar Program Nasional Pemberdayaan Masyarakat (PNPM) Mandiri, Jakarta: Tim Pengendali PNPM Mandiri 2009.

-------, Petunjuk Teknis Operasional PNPM Mandiri Pedesaan, Departemen Dalam Negeri Direktorat Pemberdayaan Masyarakat dan Desa, Jakarta: 2008.

--------, Tanya Jawab Seputar Program Nasional Pemberdayaan Masyarakat (PNPM) Mandiri, Jakarta: Tim Pengendali PNPM Mandiri, 2009.

Anwar, Khairil, “Pengertian Kemiskinan”, Makalah, IAIN Medan 2013.

Aprilani, Deddy, dan Ahmad Rifa'i, Pengaruh Jiwa Wirausaha dan Manajemen Usaha Terhadap Keberhasilan Usaha (Studi pada UMKM di Bandar Lampung). Laporan Penelitian Hibah DIPA PNBP Unila November 2007.

Balisacan, A. \& Pernia, E. \& Asra, A. 2003. Revisiting, Growth and Poverty Reduction in Indonesia: What Do Subnational Data Show?. Bulletin of Indonesian Economics Studies, Vol 39. No. 3. 
Booth, Anne, Poverty and Inequality in the Soeharto Era: An Assesment. Bulletin of Indonesian Economics Studies, Vol.36, No.1, 2000.

Cameron, Lisa A, Poverty and Inequality in Java: Examining the Impact of The Changing Age, Educational, and Industrial Structure. Journal of Development Economics, Vol. 62, 2000.

Candrasasmita, Uka, Musuh Besar Kompeni Belanda Sultan Agung Tirtayasa, Jakarta, Yayasan Kebudayaan Nusa Karang, 1967.

Chatib, Suchari, Data Perjuangan Kemerdekaan 1945, KH. TB. Achmad Chatib, Serang, Yayasan Algiffari, tanggal 28 Pebruari 1976.

Dalil Hasan, Bentuk Pengorganisasian yang Cocok untuk Mengembangkan Potensi Golongan Ekonomi Lemah dan Mengentaskan Kemiskinan, Jakarta: PT. Bineka Rena Pariwara, No. 6/VII/ 1996.

Departemen Pertanian, Metodologi Penanggulangan Kemiskinan di Indonesia Jakarta: Badan Pendidikan dan Latihan Pertanian, 1996.

Djojohadikusumo, Margono, Kenang-kenangan dari Tiga Zaman, Jakarta: PT Indera, tt.

Giddens, Antony, Studies and Social and Political Theori, London: Hutchinson \& Co Publish er Ltd, 1997.

Gunawan Sumodiningrat, Budi Santoso, Mohammad Maiwan, Kemiskinan: Teori, Fakta dan Kebijakan, Jakarta: IMPAC, 1998.

Hafizah, Yulia, Kebijakan Ekonomi Indonesia Ditinjau dari Konsep Dasar Ekonomi Islam, Jurnal Milllah Vol. IV, No. 2 Januari 2005.

Hamdzu, Data Perjuangan Kemerdekaan 1945 KH. TB.Achmad Chatib, Serang, Yayasan Al-Giffari, 24-8-1970

Hasan, Dalil, Bentuk Pengorganisasian yang Cocok untuk Mengembangkan Potensi Golongan Ekonomi Lemah dan Mengentaskan Kemiskinan, Jakarta: PT. Bineka Rena Pariwara, No. 6/VII/ 1996. 
Iradian, Garbis, Inequality, Poverty, and Growth: Cross Country Evidence. IMF Working Paper. Middle East and Central Asia Departement, 2005.

Islam, Rizwatul, The Nexus of Economic Growth, Employment and Poverty Reduction An Empirical Analysis. Report on Seminar on Accelerating Growth and Poverty Reduction in Bangladesh. ILO, Geneva, 2003.

Jawad Mugniyah, Muhammad, al-Figh ala 'al-Madzahib al-Khomsah, Beirut: Daar El-Fikr, 1996.

Kuntjoro, Mudrajad, Ekonomi Pembangunan, Teori, Masalah, dan Kebijakan, Edisi Ketiga, Yogyakarta: UPP AMP YKPN, 2003.

Mardianto, Sarul, Kemiskinan di Indonesia, Universitas Syiah Kuala, t.t.

Margono, Ichtisar Sejarah Pergerakan Nasional 1908-1945, Jakarta: Departemen Hankam Sejarah ABRI, 1971.

Mas Gogo Rafi'udin Sandjadirja, Data Perjuangan Kemerdekaan 1945 KH. TB. Achmad Chatib, Serang: Yayasan Al-Giffari, 1976.

MD, Sugimun, Peranan Pemuda dari Sumpah Pemuda Sampai Proklamasi, Jakarta: Bina Aksara, 1989.

Moeljarto Tjokrowinoto, Pengembangan Kawasan dan Pengentasan Kemiskinan dalam buku Liberalisasi Ekonomi, Pemerataan dan Kemiskinan, Yogyakarta: PT. Tiara Wacana Yogya, 1991.

Mubyarto dan Revrisond Baswir, Pelaku dan Politik Ekonomi Indonesia, Yogyakarta: Liberty, Cetakan Pertama,1989.

Muhammad, Ayip Ismail, Sejarah Banten, t.t.

M. Deden Ridwan, Ed, Metodologi Penelitian Agama, dalam tulisan U. Maman, KH. Ms., Tradisi Baru Penelitian Agama Islam Tinjauan Antar Disiplin Ilmu (Bandung: Nuansa, 2001)

Niskanen, William A, Welfare and Culture of Poverty. The Cato Jurnal, Vol. 16, No. 1, 1996. 
ODP, Sihombing, Pemuda Indonesia Menentukan Fasisme Jepang, Jakarta: Sinar Djaja, 1962.

Prasetyo, Sigit, Ahmad Rifa'i, Deddy Aprilani, Strategi-Bisnis Usaha Kecil Di Bandar Lampung, Laporan Penelitian Hibah PDM Dikti November 2007.

Rifa'i, Achmad, Data Perjuangan Kemerdekaan 1945, KH. TB. Achmad Chatib, Serang, Yayasan Algiffari, tanggal 14 April 1976

Ritonga, Hamonangan, Perkembangan Indikator Kemiskinan dan Ketena-gakerjaan Tahun 2004 dan Perkiraan Tahun 2005-2006. Journal of Quarterly Review of The Indone-sian Economy. Vol 7 (1). Januari 2006.

S. Soekanto, Sosiologi Suatu Pengantar (Jakarta: PT Raja Grafindo Persada, 1990).

Salim, Agus, (Pey)), Teori dan Paradigma Penelitian Sosial, Yogyakarta: Tiara Wacana, 2000.

Seri Kajian Fiskal dan Moneter No. 6/VII/96 "Strategi dan Evaluasi Mengentaskan Kemiskinan" Artikel, Jakarta: PT. Bina Rena Pariwara Cetakan ke 2, 1996

Sigit Prasetyo, "Studi Faktor Penyebab Kemiskinan dan Mekanisme Penanggulangan Kemiskinan di Indonesia", Makalah, Magister Ilmu Ekonomi Fakultas Ilmu Ekonomi dan Bisnis Universitas Lampung 2013.

Sirotus, L.M, Sejarah Pergerakan Kebangsaan Indonesia, Jakarta: Pustaka Rakyat NV, 1951.

Skoufias, Emmanuel, Changes in Houshold Welfare, Poverty and Inequality During The Crisis, Bulletin of Indonesian Economic Studies, Vol 36 No. 2 Augustus 2000.

Sudiyo, Perhimpunan Indonbesia Sampai Lahirnya Sumpah Pemuda. PT Mutiara Sumber Widya, 1989.

Sukherman, Maman, Assosiasi Kemiskinan Dengan Peubah Sosek di Propinsi Jawa Barat, Jurnal Kependudukan Padjadjaran. Vol. 3, No. 1, Januari 2001.

Sumodiningrat, Gunawan, Budi Santoso, Mohammad Maiwan, Kemiskinan: Teori, Fakta dan Kebijakan, Jakarta: IMPAC, 1998. 
Sumodiningrat, Gunawan, Penanggulangan Kemiskinan Melalui Kredit Pedesaan, Seri Kajian Fiskal dan Moneter No.5, Jakarta: PT. Bina Rena Pariwara Cetakan ke 2, 1996.

Suryahadi, Asep dan Sudarno Sumarto, Poverty and Vulnerability in Indonesia Before and After Economic Crisis. Asian Economic Journal. Vol 17 No. 1. 2003.

Sutomo, Cuplikan Profil Salah Seorang di antara Para Pahlawan Pendiri Negara Republik Indonesia, 1992.

Tambunan, Tulus T.H, Transformasi Ekonomi Di Indonesia, Jakarta: Salemba Empat, 2001.

-------------------, Perekonomian Indonesia, Jakarta: Penerbit Ghalia Indonesia, t.t.

Teras, Harta Karun Banten Antara Ada dan Tiada, No. 29/Edisi Nopember 2002.

Tjokrowinoto, Moeljarto, Pengembangan Kawasan dan Pengentasan Kemiskinan dalam buku Liberalisasi Ekonomi, Pemerataan dan Kemiskinan, Yogyakarta: PT. Tiara Wacana Yogya, 1999.

Todaro, Michael P, Pembangunan Ekonomi di Dunia Ketiga, Edisi Ketujuh, Jilid I. Terjemahan Hasris Munandar. Jakarta: Erlangga, 2000.

Wiratha, I Made, Metodologi Penelitian Sosial Ekonomi, Yogyakarta: Penerbit Andi, 2006.

Yulaswati, Vivi, dkk, Panduan Penggunaan Sistem Informasi Manajmen Terpadu PNPM Mandiri, Jakarta: 2009.

Itang, dosen pada Fakultas Syari'ah dan Ekonomi Islam IAIN Sultan Maulana Hasanuddin Banten. 